\title{
Health-promoting substances contained in cereals (review)
}

\author{
Milada Rakická, Ernest Šturdik, Andrea Marko \\ Department of Nutrition and Food Assessment, Institute of Biochemistry, Nutrition and Health Protection, \\ Faculty of Chemical and Food Technology, Slovak University of Technology, \\ Radlinského 9, 81237 Bratislava, Slovak Republic \\ milada.rakicka@gmail.com
}

\begin{abstract}
In current time we can see worldwide rise in number of people suffering from civilization diseases, such as health threatening cardiovascular diseases, obesity, diabetes mellitus, cancer and many others. Cereal products which provide income of important nutritional substance for human health belong among groceries with proven medical effect. Among significant components of cereals with proven effect in prevention of civilization diseases belongs roughage, $\beta$-glucans, phytochemicals. Important role also play vitamins and minerals, which are present in cereals in minor values. Article summarizes presence of medically important substances in cereals.
\end{abstract}

Keywords: cereals, dietary fibre, $\beta$-glucans, phytochemicals

\section{Introduction}

Botanically, cereals belong to the monocot family Poaceae. Wheat, rye, and barley are closely related as members of the subfamily Pooideae and the tribus Triticeae. Oats are a distant relative of the Triticeae within the subfamily Pooideae, whereas rice, corn, sorghum, and millet show separate evolutionary lines (Koehler and Wieser 2013). Cereals produce dry, one-seeded fruits, called the "kernel" or "grain", in the form of a caryopsis, in which the fruit coat (pericarp) is strongly bound to the seed coat (testa). Grain size and weight vary widely from rather big corn grains $(\sim 350 \mathrm{mg})$ to small millet grains $(\sim 9 \mathrm{mg})$. The anatomy of cereal grains is fairly uniform: fruit and seed coats (bran) enclose the germ and the endosperm, the latter consisting of the starchy endosperm and the aleurone layer. In oats, barley, and rice the husk is fused together with the fruit coat and cannot be simply removed by threshing as can be done with common wheat and rye (naked cereals) (Belitz et al 2009). Cereal grains are an important energy source throughout the world. Grain-based foods provide the majority of the carbohydrate and dietary fibre intakes in many countries (FAO 2011). The major cereals consumed worldwide are wheat, rice, maize, barley, oats, rye, millet, sorghum. In Europe, the average annual consumption of cereal grains is $131 \mathrm{~kg}$ per capita, wheat making up the majority of it (108 kg/capita/year), whereas in Asia, about half of the annual cereal consumption is rice. Apart from being an important part of diet, these cereals are also rich in various health promoting compo- nents (Slavin 2003). Cereals contain a range of substances which may have health promoting effects, these substances are often referred to as Phytochemicals or Plant bioactive substances (Goldberg 2003).

\section{Chemical composition of cereals}

The cereal grain is a sophisticated reservoir of macronutrients, cell wall polysaccharides (dietary fibre) and many biologically active minor constituents (Fig. 1).
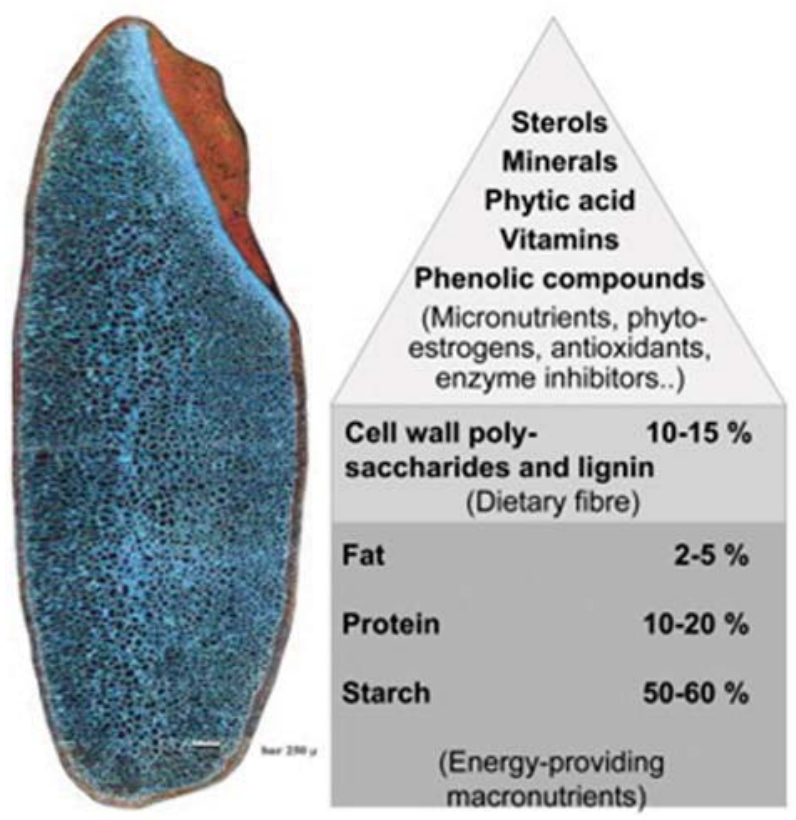

Fig. 1. The cereal grain is a versatile raw material (Poutanen 2012). 


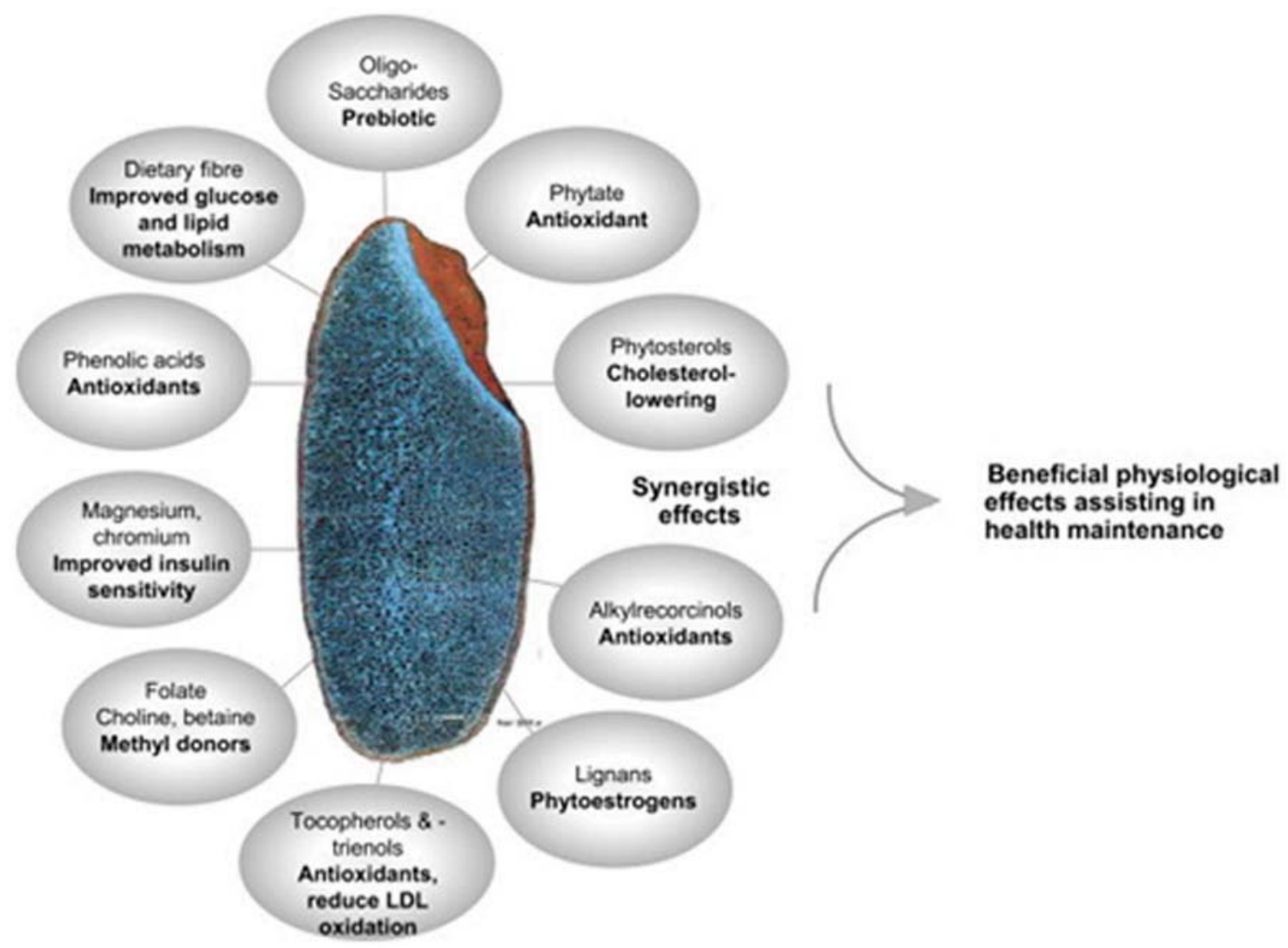

Fig. 2. The many bioactive compounds present in the grain most probably act in synergy to influence the human metabolism (Poutanen 2012).

The starchy endosperm gathered most of the scientific and technological interest for food processing until the end of the previous century. The recognition of the importance of the outer grain layers for health maintenance created the interest to reveal the types, amounts and potential physiological significance of various vitamins, minerals and phytochemicals in the whole grain and food made thereof (Fig. 2) (Kong and Singh 2008).

\section{Carbohydrates}

Cereal grains contain 66-76\% carbohydrates (Tab. 1), thus, this is by far the most abundant group of constituents. The major carbohydrate is starch (55-70\%) followed by minor constituents such as arabinoxylans (1.5-8 \%), $\beta$-glucans $(0.5-7 \%)$, sugars $(\sim 3 \%)$, cellulose $(\sim 2.5 \%)$, and glucofructans ( 1\%) (Koehler and Wieser 2013). Dietary carbohydrates can be divided very simply into two major groups solely on the basis of their

Tab. 1. The content and characteristics of starch from various cereals.

\begin{tabular}{lcccc}
\hline Origin & Starch $(\% \mathbf{D M})$ & Amylose content $(\%)$ & Granule size & Gelatinization tem. $\left({ }^{\circ} \mathbf{C}\right)$ \\
\hline Non-viscous grains & & & & $62-72$ \\
Maize & 75 & 28 & $2-30$ & $63-72$ \\
Waxy maize & 75 & 0,8 & $4-28$ & 67 \\
Hi-maize & 74 & 52 & $4-22$ & $68-78$ \\
Sorghum & 68 & - & $3-27$ & $68-78$ \\
Rice & 80 & 18,5 & - & $58-64$ \\
Viscous grain & & & $3-35$ & $57-70$ \\
Wheat & 65 & 26 & - & $52-60$ \\
Rye & 60 & - & $2-40$ & \\
Barley & 55 & 22 & & \\
\hline
\end{tabular}


susceptibility to digestion by human small intestinal enzymes. Humans possess a suite of small intestinal digestive enzymes but only one ( $\alpha$-amylase) that can attack a complex carbohydrate. This enzyme can hydrolyse only one significant dietary polysaccharidestarch. This specificity depends on the presence of $\alpha$-1,4-glucosidic links in the target polysaccharide. All of other major complex carbohydrates (oligosaccharides and non-starch polysaccharides) seem to resist human small intestinal enzymic digestion completely (Spiller 1993). Starch occurs only in the endosperm and is present in granular form. It consists of two water-insoluble homoglucans-amylose and amylopectin. Cereal starches are typically composed of 25-28\% amylose and 72-75\% amylopectin (Colonna, Buléon 1992). Amylose consists of $\alpha$-(1,4)-linked D-glucopyranosyl units and is almost linear. Parts of the molecules also have $\alpha-(1,6)$ linkages providing slightly branched structures (Shibanuma et al. 1994). The degree of polymerization ranges from 500 to 6,000 glucose units giving a molecular weight (MW) of $8 \times 10^{4}$ to $10^{6}$. Amylopectin is responsible for the granular nature of starch. It contains 30,000-3,000,000 glucose units and, therefore, it has a considerably higher MW $\left(10^{7}-10^{9}\right)$ than amylose (Buléon 1998). Amylopectin is a highly branched polysaccharide consisting of $\alpha$-(1,4)-linked-D-glucopyranosyl chains, which are interconnected via $\alpha$-(1,6)-glycosidic linkages, also called branch points (Zobel 1988). Polysaccharides other than starch are primarily constituents of the cell walls and are much more abundant in the outer than in the inner layers of the grains. Therefore, a higher extraction rate is associated with a higher content of non-starch polysaccharides. From a nutritional point of view non-starch polysaccharides are dietary fiber, which has been associated with positive health effects (Babio et al 2010).

\section{Proteins}

Quality of cereal proteins is determined by their amino acid composition and digestibility. Cereal proteins are the source of most essential amino acids (Tab. 2), except for lysine and tryptophan (Bekes et al. 2004). Proteins are distributed over the whole grain, their concentration within each compartment, however, is remarkably different. Typical of all flours is the fact that glutamic acid almost entirely occurs in its amidated form as glutamine (Wieser et al 1983). This amino acid generally predominates (15-31\%), followed by proline in the case of wheat, rye, and barley (12-14\%). Further major amino acids are leucine $(7-14 \%)$ and alanine (4-11\%). The nutritionally essential amino acids tryptophan $(0.2-1.0 \%)$, methionine (1.3-2.9\%), histidine $(1.8-2.2 \%)$, and lysine $(1.4-3.3 \%)$ are present only at very low levels (Koehler and Wieser 2013).

Tab. 2. The content of amino acids in cereals (Wieser et al 1983).

\begin{tabular}{|c|c|c|c|c|c|c|c|}
\hline Amino acid & Wheat & Rye & Barley & Oats & Rice & Millet & Corn \\
\hline $\operatorname{Asx}^{*}$ & 4,2 & 6,9 & 4,9 & 8,1 & 8,8 & 7,7 & 5,9 \\
\hline Thr & 3,2 & 4,0 & 3,8 & 3,9 & 4,1 & 4,5 & 3,7 \\
\hline Ser & 6,6 & 6,4 & 6,0 & 6,6 & 6,8 & 6,6 & 6,4 \\
\hline Glx* & 31,1 & 23,6 & 24,8 & 19,5 & 15,4 & 17,1 & 17,7 \\
\hline Pro & 12,6 & 12,2 & 14,3 & 6,2 & 5,2 & 7,5 & 10,8 \\
\hline Gly & 6,1 & 7,0 & 6,0 & 8,2 & 7,8 & 5,7 & 4,9 \\
\hline Ala & 4,3 & 6,0 & 5,1 & 6,7 & 8,1 & 11,2 & 11,2 \\
\hline Cys & 1,8 & 1,6 & 1,5 & 2,6 & 1,6 & 1,2 & 1,6 \\
\hline Val & 4,9 & 5,5 & 6,1 & 6,2 & 6,7 & 6,7 & 5,0 \\
\hline Met & 1,4 & 1,3 & 1,6 & 1,7 & 2,6 & 2,9 & 1,8 \\
\hline Ile & 3,8 & 3,6 & 3,7 & 4,0 & 4,2 & 3,9 & 3,6 \\
\hline Leu & 6,8 & 6,6 & 6,8 & 7,6 & 8,1 & 9,6 & 14,1 \\
\hline Tyr & 2,3 & 2,2 & 2,7 & 2,8 & 3,8 & 2,7 & 3,1 \\
\hline Phe & 3,8 & 3,9 & 4,3 & 4,4 & 4,1 & 4,0 & 4,0 \\
\hline His & 1,8 & 1,9 & 1,8 & 2,0 & 2,2 & 2,1 & 2,2 \\
\hline Lys & 1,8 & 3,1 & 2,6 & 3,3 & 3,3 & 2,5 & 1,4 \\
\hline Arg & 2,8 & 3,7 & 3,3 & 5,4 & 6,4 & 3,1 & 2,4 \\
\hline $\operatorname{Trp}$ & 0,7 & 0,5 & 0,7 & 0,8 & 0,8 & 1,0 & 0,2 \\
\hline Amide group & 31,0 & 24,4 & 26,1 & 19,2 & 15,7 & 22,8 & 9,8 \\
\hline
\end{tabular}

${ }^{\mathrm{a}}$ Asx Asp + Asn, Glx Glu + Gln 
Traditionally, cereal flour proteins have been classified into four fractions albumins (water soluble proteins), globulins (salt soluble proteins), prolamins (alcohol soluble proteins), and glutelins (acid or base soluble proteins) (Osborne 1907). Albumins and globulins are concentrated in the aleurone layer, bran, and germ, whereas their concentration in the starchy endosperm is relatively low. Predominantly, prolamins and glutelins are the storage proteins of cereal grains. Their only biological function is to supply the seedling with nitrogen and amino acids during germination. They are located in the starchy endosperm only. The prolamin fractions of the different cereals have been given trivial names: gliadin (wheat), secalin (rye), hordein (barley), avenin (oats), zein (corn), kafirin (millet, sorghum), and oryzin (rice) (Koehler and Wieser 2013).

\section{Lipids}

Cereal lipids originate from membranes, organelles, or spherosomes and consist of different chemical structures. Depending on cereal species average lipid contents of $1.7-7 \%$ in the grains are present. Lipids are mainly stored in the germ, to a smaller extent in the aleurone layer and to the lesser extent in the endosperm. In particular, oats are rich in lipids $(6-8 \%)$ in contrast to wheat and rye $(1.7 \%)$. Cereal lipids have similar fatty acid compositions (Tab. 3), in which linoleic acid reaches contents of 39-69\%, while oleic acid and palmitic acid make up $11-36 \%$ and $18-28 \%$, respectively (Delcour and Hoseney 2010) .

While triglycerides are the dominating lipid class in the germ and the aleurone layer, phospho- and glycolipids are present in the endosperm (Fig. 3). De-

Tab. 3. Fatty-acid composition of cereals: Representative values in grams per $100 \mathrm{~g}$ total fatty acids (total includes $2-3 \%$ of trace fatty acids) (Caballero et al 2005).

\begin{tabular}{|c|c|c|c|c|c|}
\hline & $\begin{array}{l}\text { Palmic acid } \\
\quad(16: 0)\end{array}$ & $\begin{array}{c}\text { Stearic acid } \\
\quad(18: 0)\end{array}$ & $\begin{array}{c}\text { Oleic acid } \\
(18: 1)\end{array}$ & $\begin{array}{c}\text { Linoleic acid } \\
(18: 2)\end{array}$ & $\begin{array}{c}\text { Linolenic acid } \\
(18: 3)\end{array}$ \\
\hline Rice & 22 & 2 & 34 & 38 & 2 \\
\hline Maize & 12 & 2 & 32 & 50 & 2 \\
\hline Wheat & 18 & 2 & 18 & 56 & 3 \\
\hline Barley & 22 & 1 & 13 & 56 & 5 \\
\hline Sorghum & 13 & 2 & 34 & 46 & 2 \\
\hline Pearl millet & 20 & 4 & 26 & 44 & 3 \\
\hline Foxtail millet & 10 & 3 & 17 & 64 & 3 \\
\hline Proso millet & 9 & 2 & 21 & 64 & 2 \\
\hline Finger millet & 24 & 2 & 46 & 24 & 1 \\
\hline Kodo millet & 18 & 2 & 36 & 40 & 2 \\
\hline Oats & 19 & 2 & 36 & 38 & 2 \\
\hline Rye & 15 & 1 & 17 & 58 & 7 \\
\hline
\end{tabular}

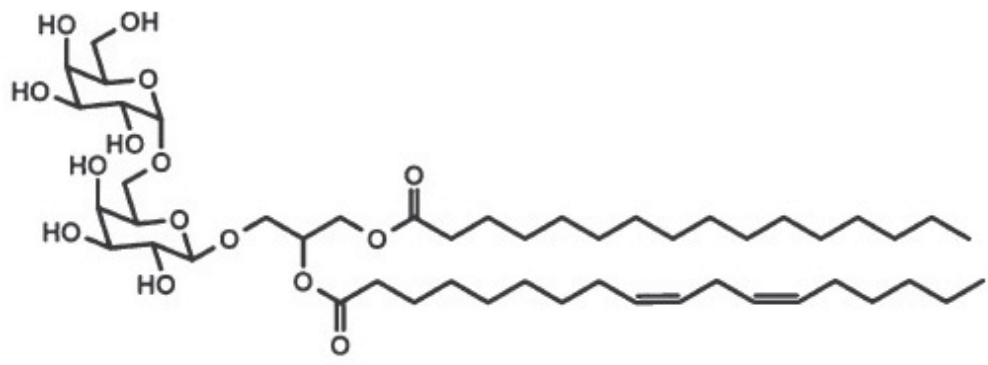

glycolipids (digalactosyldiglyceride)

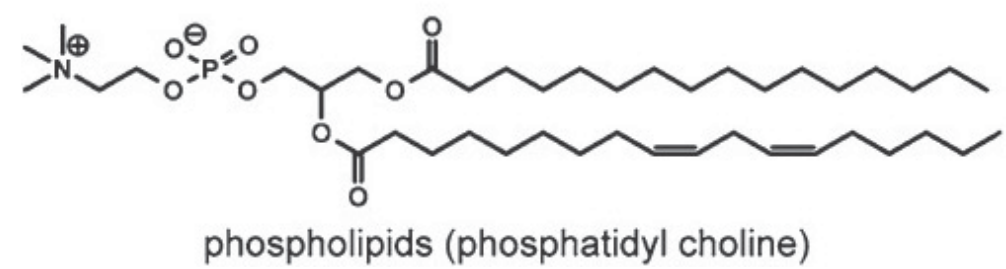

Fig. 3. Polar lipids of cereals. 
pending on the extraction rate wheat flour contains 0.5-3 \% lipids (Hoseney 1994). They contain about $60 \%$ non-polar lipids, $24 \%$ glycolipids, and $15 \%$ phospholipids. The non-polar lipids are mainly present in the free lipid fraction, whereas glycoand phospholipids are part of the bound fraction, in which they can be associated, for example with proteins (Delcour and Hoseney 2010).

\section{Health beneficial components}

In cereals, we can find many nutritional value components including dietary fiber, $\beta$-glucans, phytochemicals, vitamins, minerals and others. These substances provide many health beneficial effects.

\section{Dietary fibre}

The term 'dietary fiber' (Tab. 4) first came into existence in 1953 and included cellulose, hemicelluloses and lignin (Hispley 1953). The main physiological characteristic of dietary fiber is its non-digestibility in the small intestine. It mainly comprises the portions of food that are not broken down by the secreted agents of the human digestive tract. Types of dietary fiber may also be categorized according to their sources, solubility, fermentability and physiological effects. (Champ et al 2003). In cereal grain, a majority of fibre is found (at a decreasing rate) from the outer coat to the endosperm.

Dietary fiber consists primarily of carbohydrate polymers (non-starch polysaccharides) that are components of plant cell walls, including cellulose, hemicelluloses and pectins, as well as other polysaccharides of plant or algal origin, such as gums and mucilages and oligosaccharides such as inulin (Theuwissen and Mensink 2008). Analogous nondigestible carbohydrates that pass through the small intestine unchanged but are fermented in the large intestine should also be included, for example resistant starch, fructo-oligosaccharides, galacto-oligosaccharides, modified celluloses and synthesized carbohydrate polymers, such as polydextrose (Alonso and Pérez 2005). Associated substances, principally lignin, and minor compounds including waxes, cutin, saponins, polyphenols, phytates and phytosterols, are also included, as they are extracted with the polysaccharides and oligosaccharides in various fiber analytical methods (Guillon and Champ. 2000). However, with the exception of lignin, these associated substances when isolated, could not be described as dietary fiber.

Published reports indicate numerous health benefits associated with an increased intake of dietary fibre, including reduced risk of coronary heart disease, diabetes, obesity, and some forms of cancer (Mann

Tab. 4. Definitions of dietary fibre.

\begin{tabular}{ll}
\hline American Association of Cereal Chemists (AACC, 2001) & $\begin{array}{l}\text { Definition } \\
\text { The edible part of plants or analogous carbohydrates that } \\
\text { intestine, with complete or partial fermentation in the large } \\
\text { intestine. }\end{array}$ \\
\hline Codex Alimentarius Commission (CAC, 2006) & $\begin{array}{l}\text { Carbohydrate polymers with a degree of polymerization } \\
\text { not lower than 3, which are neither digested nor absorbed } \\
\text { in the small intestine. A degree of polymerization not lower } \\
\text { than } 3 \text { is intended to exclude mono- and disaccharides. It } \\
\text { is not intended to reflect the average degree of polymeriza- } \\
\text { tion of a mixture. }\end{array}$
\end{tabular}

Codex Commision on Nutrition and Foods

for Special Dietary Uses

Carbohydrate polymers with ten or more monomeric units, which are not hydrolysed by endogenous enzymes in small intestine of human beings and belong to the following three categories: 1) edible carbohydrate polymers naturally occurring in food as consumed, 2) carbohydrate polymers, which have been obtained from raw material in food by physical, enzymatic, or chemical means and which have been shown to have physiological effect of benefit to health by generally accepted scientific evidence to competent authorities and 3) Synthetic carbohydrate polymers, which have been shown to have physiological effect of benefit to health by generally accepted scientific evidence to competent authorities (Cummings et al. 2009).

Dietary Reference Intake (DRI)

It divides fibre into 3 categories of 1 ) dietary fibre (includes wheat and oat bran), 2) functional fibre (includes resistant starches) and 3) total fibre, which is the sum of dietary and functional fibre (Trumbo et al 2002). 
and Cummings 2009). Oat bran, barley bran, and psyllium, mostly soluble fibre, have earned a healthy reputation for their ability to lower blood lipid levels. Wheat bran and other more insoluble fibres are typically linked to laxative properties (American Dietetic Association 2008).

Supplementation with dietary fibre can result in fitness-promoting foods, low in calories, cholesterol and fat. According to current recommendations (Food and Nutrition Board, Institute of Medicine 2001), the average daily requirement of dietary fibre is $25 \mathrm{~g}$ per day for women younger than 50 , $21 \mathrm{~g}$ per day for women older than $50 ; 38 \mathrm{~g}$ per day for men younger than 50 , and $30 \mathrm{~g}$ per day for men older than 50. Most nutritionists and diet experts suggest that ca $20-30 \%$ of our daily fibre intake should come from soluble fibre.

\section{Resistant starch}

Starch and starch degradation products that are indigestible by enzymes in the small intestine of healthy humans are referred to as resistant starch. Resistant starch positively influences the functioning of the digestive tract, microbial flora, the blood cholesterol level, the glycemic index and assists in the control of diabetes. Apart from the potential health benefits of resistant starch, another positive advantage is its lower impact on the sensory properties of food compared with traditional sources of fibre, as whole grains, fruits or bran (Zaragoza et al. 2010). Resistant starches are divided in four sub-fractions (Tab. 5): physically inaccessible starch $\left(\mathrm{RS}_{1}\right)$, native starch granules $\left(\mathrm{RS}_{2}\right)$, retrograded starch $\left(\mathrm{RS}_{3}\right)$ and chemically modified starch $\left(\mathrm{RS}_{4}\right)$. Table outlines a summary of the dif- ferent types of resistant starch, their resistance to digestion in the small intestine and food sources of each type of RS (Lunn and Buttriss 2007).

\section{$\beta$-glucans}

$\beta$-glucans are indigestible polysaccharides occurring naturally in various organic sources such as corn grains, yeasts, bacteria, algae. They are important components of the fibres containing non-branched polysaccharides consisting of $\beta$-D-glucopyranose units linked through $(1 \rightarrow 4)$ and $(1 \rightarrow 3)$ glycosidic bonds in cereals (Fig. 4 ) and $(1 \rightarrow 6)$ glycosidic bonds in fungal sources, respectively. The structure has an impact on the water solubility of $\beta$-glucans (Johansson et al. 2000, Ren et al. 2003).

Glucans are usually concentrated in the internal aleurone and sub-aleurone endosperm cells walls (Holtekjolen et al. 2006). Out of cereals, the highest amounts of $\beta$-glucans are found in barley and oat grains (Havrlentová \& Kraic 2006). The FDA determined that an effective daily intake of $\beta$-glucan is $3 \mathrm{~g}$, but there have been few attempts to establish a dose response (which may differ among different subject groups and depend upon baseline level). The primary sources of $\beta$-glucan in the human diet from cereals are oats, barley, rye and wheat. The levels in dehulled or naked oats and most dehulled or naked barleys range mostly from about $3 \%$ to $7 \%$ (Wood 1994), in rye $2 \%$ (Ragaee et al. 2001) and in wheat $<0.5 \%$ (Beresford and Stone 1983). Milling to separate coarse particle fractions is used to increase the levels of $\beta$-glucan (Dexter and Wood 1996; Nilsson et al. 1997, Wood et al. 1989). Cereal $\beta$-glucans are linear polysaccharides which

Tab. 5. Types of resistant starch, their resistance to digestion in small intestine and food sources (Sharma and Yadav 2008, Lunn and Buttriss 2007, Sajilata et al. 2006, Nugent 2005).

\begin{tabular}{|c|c|c|c|c|}
\hline $\begin{array}{l}\text { Type } \\
\text { of } \\
\text { starch }\end{array}$ & Description & $\begin{array}{l}\text { Digestion in small } \\
\text { intestine }\end{array}$ & $\begin{array}{l}\text { Resistance } \\
\text { reduced by }\end{array}$ & Food sources \\
\hline RS1 & $\begin{array}{l}\text { Physically inaccessible to } \\
\text { digestion by entrapment in } \\
\text { a non-digestible matrix }\end{array}$ & $\begin{array}{l}\text { Slow rate; partial degree } \\
\text { Totally digested of } \\
\text { properly milled }\end{array}$ & Milling, chewing & $\begin{array}{l}\text { Whole or partly milled grains } \\
\text { and seeds, legumes, pasta }\end{array}$ \\
\hline RS2 & $\begin{array}{l}\text { Non-gelatinized resistant } \\
\text { granules with type B } \\
\text { crystallinity, slowly } \\
\text { hydrolyzed by } \alpha \text {-amylase }\end{array}$ & $\begin{array}{l}\text { Very slow rate; little } \\
\text { degree } \\
\text { Totally digested when } \\
\text { freshly cooked }\end{array}$ & $\begin{array}{l}\text { Food processing } \\
\text { and cooking }\end{array}$ & $\begin{array}{l}\text { Raw potatoes, green bananas, } \\
\text { some legumes, high-amylose } \\
\text { starches }\end{array}$ \\
\hline RS3 & $\begin{array}{l}\text { Retrograded starch formed } \\
\text { when starch-containing } \\
\text { foods are cooked and } \\
\text { cooled }\end{array}$ & $\begin{array}{l}\text { Slow rate; partial degree } \\
\text { digestibility improved by } \\
\text { reheating }\end{array}$ & $\begin{array}{l}\text { Processing } \\
\text { conditions }\end{array}$ & $\begin{array}{l}\text { Cooked and cooled potatoes, } \\
\text { bread, corn- flakes, food } \\
\text { products with prolonged and/or } \\
\text { repeated moist heat treatment }\end{array}$ \\
\hline RS4 & $\begin{array}{l}\text { Selected chemically- } \\
\text { modified resistant starches } \\
\text { and industrially processed } \\
\text { food ingredients }\end{array}$ & $\begin{array}{l}\text { As a result of chemical } \\
\text { modification, can resist } \\
\text { hydrolysis }\end{array}$ & $\begin{array}{l}\text { Less susceptible } \\
\text { to digestibility } \\
\text { in vitro }\end{array}$ & $\begin{array}{l}\text { Some fibre: drinks, foods in } \\
\text { which modified starches have } \\
\text { been used (certain breads and } \\
\text { cakes) }\end{array}$ \\
\hline
\end{tabular}




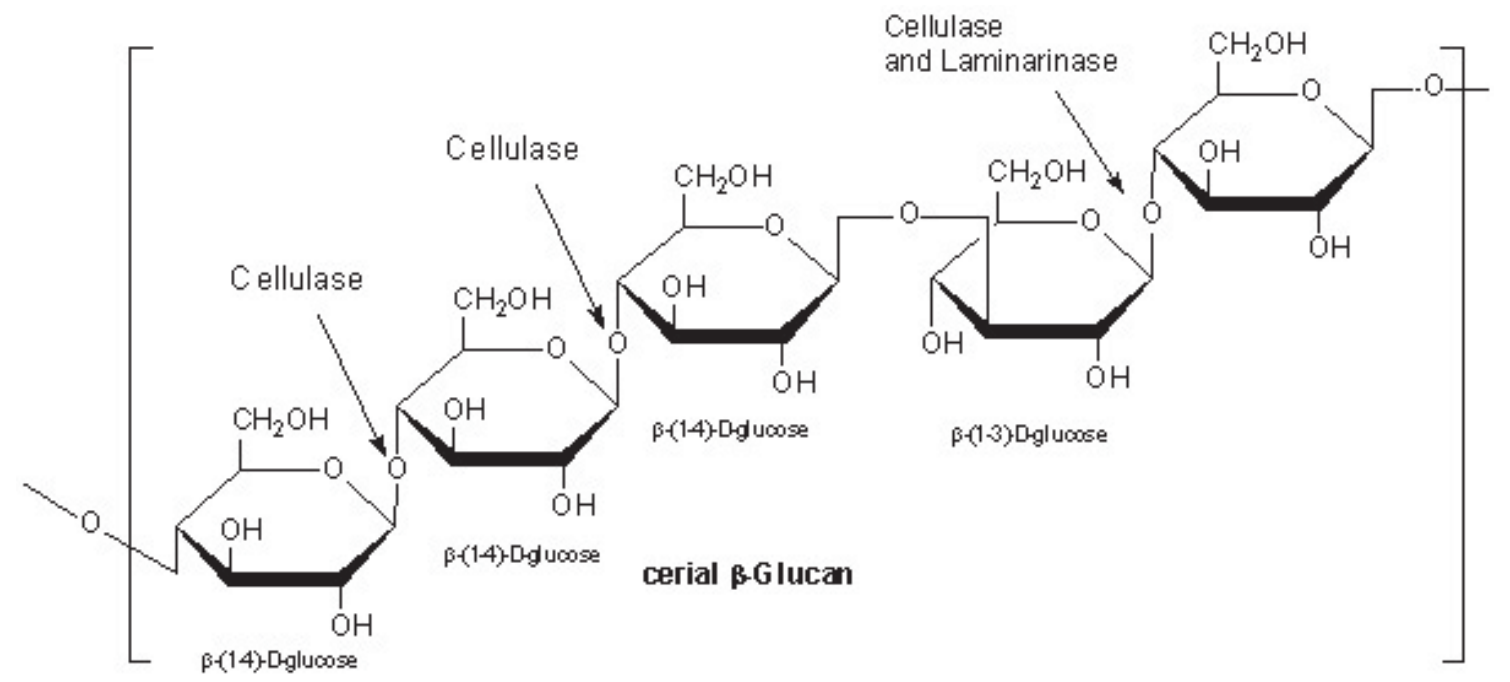

Fig. 4. Basic structure of $\beta$-glucans in cereals with combined bonds $\beta-(1-3)$ and $\beta$-(1-4).

can be viewed as a cellulose chain ( $70 \%$ 4-Olinked $\beta$-D-glucopyranosyl units) interrupted by 3-O-linked $\beta$-D-glucopyranosyl units $(\sim 30 \%)$. The $(1 \rightarrow 3)$ linkages occur singly, leading to a structure of predominantly $\beta$-( $1 \rightarrow 3)$-linked cellotriosyl and cellotetraosyl units (Parrish et al. 1960). The molar ratio of $(1 \rightarrow 3)$-linked cellotriosyl to $(1 \rightarrow 3)$-linked cellotetraosyl units, which constitute $85-90 \%$ by weight of the cereal $\beta$-glucan (Skendi et al. 2003), is lower in oats (2.1-2.4) than in barley (2.8-3.3), rye (3.0-3.2) or wheat (3.0-4.5) (Cui et al. 2000). Cellulose-like sequences containing more than three consecutive $\beta$-( $1 \rightarrow 4$ )-linked D-glucopyranosyl units are present at less than $15 \%$ of the polysaccharide, and seem to be conserved amongst all the cereal $\beta$-glucans.

The cholesterol lowering ability of $\beta$-glucans is considered to result from effects manifested in the upper gastrointestinal tract which may be related to their ability to form a gel-like network and alter gastrointestinal viscosity (Reimer et al. 2000).

\section{Phytochemicals}

The majority of phytochemicals of whole grains that are beneficial for health are present in the bran/ germ fraction. In whole wheat flour, the bran/ germ fraction contributed $83 \%$ of total phenolic content, $79 \%$ of total flavonoid content, $78 \%$ of total zeaxanthin, $51 \%$ of total lutein, and $42 \%$ of total $\beta$-cryptoxanthin. Cereal products are a significant natural plant sterol source (free, esterified and steryl glycosides, which are the most common form in cereals) ( $\mathrm{Liu}, 2007$ ).

The total sterol contents of rye $(95.5 \mathrm{mg} / 100 \mathrm{~g}$, wb), wheat (69.0), barley (76.1) and oat (44.7) have been reported in Finland (Piironen et al. 2002). A median total phytosterol concentration of $49 \mathrm{mg} / 100 \mathrm{~g}$ (range 4.1-344) edible portion has been reported for some cereal foods commonly consumed in Sweden and in the Netherlands, $\beta$-sitosterol generally being the dominant form (62\%), followed by campesterol $(21 \%)$ and, in smaller concentrations, stigmasterol (4\%), $\beta$-sitostanol (4\%) and campestanol (2\%) (Normén, 2002). Free and esterified sterol contents of 52.7 and $52.8 \mathrm{mg} / 100 \mathrm{~g}$, respectively, have been reported in spelt (Triticum spelta) and winter wheat (Triticum aestivum), which also contain 123.8 and $112.6 \mathrm{mg} / 100 \mathrm{~g}$, respectively, of glycosylated sterols (Ruibal-Mendieta, 2004). Plant sterols (phytosterols) are bioactive components of all vegetable foods. They are 28- or 29-carbon alcohols and resemble cholesterol in vertebrates in terms of both function (stabilization of phospholipid bilayers in plant cell membranes) and structure (steroid nucleus, 3ß-hydroxyl group, 5, 6 double bond). Phytosterols contain an extra methyl or ethyl group, or double bond; most phytosterol side chains contain 9-10 carbon atoms, instead of 8 as found in cholesterol. Phytosterols have been classified as 4-demethylsterols of the cholestane series, all of which have double bonds at the C-5 position of the ring (Kritchevskya and Shirley 2005).

Various classes of phenolic compounds in grains include phenolic acids, anthocyanidins, quinones, flavonols, chalcones, flavones, flavanones, and amino phenolic compounds (Lloyd et al. 2000; Maillard and Berset 1995). Some of these phytochemicals such as ferulic acid and diferulates are predominantly found in grains but are not present in significant quantities in some fruits and vegetables (Bunzel et al. 2001). Grains also contain tocotrienols, tocopherols, and oryzanols (Lloyd et al., 2000). These phytochemicals play important structural and defense roles in grains. The types of grains and varieties influence the concentration of whole grain phytochemicals (Adom et al. 2003). The most important groups of 
phytochemicals found in whole grains can be classified as phenolics, carotenoids, vitamin E compounds, lignans, $\beta$-glucan, and inulin. Most whole grain phenolics are in bound form, $85 \%$ in corn, $76 \%$ in wheat, and $75 \%$ in oats.

Phenolics are compounds possessing one or more aromatic rings with one or more hydroxyl groups, and generally are categorised as phenolic acids, flavonoids, stilbenes, coumarins, and tannins (Liu 2004). Phenolics are the products of secondary metabolism in plants, providing essential functions in the reproduction and growth of the plants, acting as defense mechanisms against pathogens, parasites, and predators, as well as contributing to the colour of plants. Phenolic compounds have antioxidant properties and protect against degenerative diseases like heart diseases and cancer in which reactive oxygen species i.e., superoxide anion, hydroxyl radicals and peroxyl radicals are involved (Harborne and Williams 2000, Rhodes and Price, 1997). Emerging research has also suggested that undigested polyphenols associated with dietary fiber may provide important protection at the intestinal environment level (Vitaglione et al. 2008, Saura-Calixto 2011). Current public health recommendations aimed at reducing the risk of coronary heart disease in the UK suggest including oats and oat-based products as part of a healthy diet. The concentration of phenolic compounds in whole-grain cereals is influenced by grain types, varieties and the part of the grain sampled (Adom et al. 2005).

Phenolic acids and flavonoids represent the most common form of phenolic compounds found in whole grains, and they are among the major and most complex groups of phytochemicals with a number of types that exist as soluble free compounds, soluble conjugates that are esterified to sugars and other low molecular mass compounds, and insoluble, bound forms (Piironen et al. 2009). Sorghum and millet have the widest variety of phenolic acids. Free phenolic acids are found in outer layer of the pericarp (Mattila et al. 2005; Subba and Muralikrishna, 2002). Bound phenolic acids are esterified to cell walls; acid or base hydrolysis is required to release these bound compounds from the cell matrix (Kim et al. 2006; Robbins 2003). The major phenolic acids in cereals are ferulic acids and p-coumaric acid (Holtekjølen et al. 2006). Phenolic acids can be subdivided into two major groups, hydroxybenzoic acid and hydroxycinnamic acid derivatives (Fig. 6). Hydroxybenzoic acid derivatives include $p$-hydroxybenzoic, protocatechuic, vanillic, syringic, and gallic acids (Mattila et al. 2005). They are commonly present in the bound form and are typically components of complex structures such as lignins and hydrolyzable tannins. They can also be found as derivatives of sugars and organic acids in plant foods. Hydroxycinnamic acid derivatives include p-coumaric, caffeic, ferulic, and sinapic acids (Devanto et al. 2002). They are mainly present in the bound form, linked to cell wall structural components such as cellulose, lignin, and proteins through ester bonds. The common phenolic acids found in whole grains include ferulic acid, vanillic acid, caffeic acid, syringic acid, and $p$-coumaric acid (Sosulski et al. 1982) (Fig. 5).

Ferulic acid (trans-4-hydroxy-3-methoxycinnamic acid) is one of the most common phenolic acids found in whole grains (Abdel-Aal et al. 2001; Yang et al. 2001). It is abundant in the aleurone, pericarp, and embryo cell walls of various grains, but occurs only in trace amounts in the starchy endosperm (Smith and Hartley 1983). Wheat bran is a good source of ferulic acids, which are esterified to hemicellulose of the cell walls. Food processing, such as thermal processing, pasteurisation, fermentation, and freezing, contributes to the release of these bound phenolic acids (Dewanto et al., 2002). Ferulic acid and other phenolic acids protect wheat kernels by providing both physical and chemical barriers through cross-linking carbohydrates, antioxidant activities to combat destructive radicals, and astringency that deters consumption by insects and animals (Arnason et al. 1992). Ferulic acid can exist in the free, soluble-conjugated, and bound forms in whole grains. Bound ferulic acid was significantly higher (>93\% of total) than free and soluble-conjugated ferulic acid in corn, wheat, oats, and rice (Adom and Liu 2002). The ratio of free, soluble-conjugated, and bound ferulic acid in corn and wheat was 0.1:1:100. The order of total ferulic acid content among the tested grains was corn > wheat >oats > rice (Adom and Liu 2002).

\section{Carotenoids}

Carotenoids represent a large group of phytochemicals with function to protect plants from photo-induced free radical damage (DammigAdams et al. 1996). They also provide colour in whole grain flour (Liu 2007). Carotenoids commonly found in whole grains are lutein, zeaxanthin, $\beta$-cryptoxanthin, $\beta$-carotene, and $\alpha$-carotene (Abdel-Aal et al. 2007, Adom et al. 2005). Generally speaking, lutein is the carotenoid present in the highest concentration in wheat, followed by zeaxanthin, and then $\beta$-cryptoxanthin (Liu 2007). Rice bran contains both lutein and zeaxanthin, which improves eye sight. Cereals are the source of carotenoids (Saikia and Deka 2011). Maize is the best source with about $11 \mu \mathrm{g} / \mathrm{kg}$ on dry 


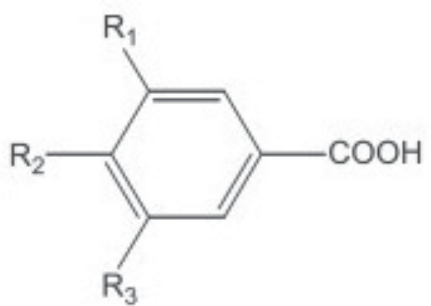

\begin{tabular}{lccc}
\hline \multirow{2}{*}{$\begin{array}{l}\text { Benzoic acid } \\
\text { derivatives }\end{array}$} & $\mathrm{R}_{1}$ & $\mathrm{R}_{2}$ & $\mathrm{R}_{3}$ \\
\cline { 2 - 4 } Benzoic acid & $\mathrm{H}$ & $\mathrm{H}$ & $\mathrm{H}$ \\
\hline p-Hydroxybenzoic acid & $\mathrm{H}$ & $\mathrm{OH}$ & $\mathrm{H}$ \\
\hline Protocatechuic acid & $\mathrm{H}$ & $\mathrm{OH}$ & $\mathrm{OH}$ \\
\hline Vannilic acid & $\mathrm{CH}_{3} \mathrm{O}$ & $\mathrm{OH}$ & $\mathrm{H}$ \\
\hline Syringic acid & $\mathrm{CH}_{3} \mathrm{O}$ & $\mathrm{OH}$ & $\mathrm{CH}_{3} \mathrm{O}$ \\
\hline Gallic acid & $\mathrm{OH}$ & $\mathrm{OH}$ & $\mathrm{OH}$ \\
\hline
\end{tabular}

b

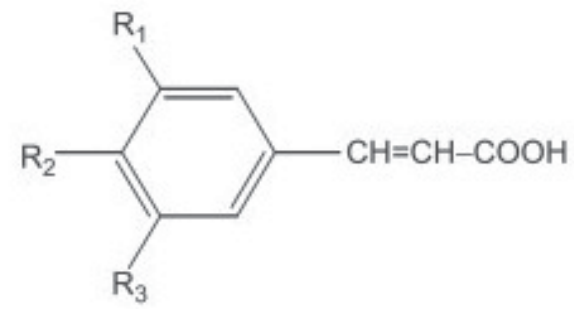

\begin{tabular}{lccc}
\hline Cinnamic acid & \multicolumn{3}{c}{ Substitutions } \\
\cline { 2 - 4 } derivatives & $\mathrm{R}_{1}$ & $\mathrm{R}_{2}$ & $\mathrm{R}_{3}$ \\
\hline Cinnamic acid & $\mathrm{H}$ & $\mathrm{H}$ & $\mathrm{H}$ \\
\hline p-Coumaric acid & $\mathrm{H}$ & $\mathrm{OH}$ & $\mathrm{H}$ \\
\hline Caffeic acid & $\mathrm{OH}$ & $\mathrm{OH}$ & $\mathrm{H}$ \\
\hline Ferulic acid & $\mathrm{CH}_{3} \mathrm{O}$ & $\mathrm{OH}$ & $\mathrm{H}$ \\
\hline Sinapic acid & $\mathrm{CH}_{3} \mathrm{O}$ & $\mathrm{OH}$ & $\mathrm{CH}_{3} \mathrm{O}$ \\
\hline
\end{tabular}

Fig. 5. Structures of common phenolic acids: (a) benzoic acid derivatives and (b) cinnamic acid derivatives.

weight basis (Panfili et al. 2004). Carotenoids are classified into hydrocarbons (carotenes) and their oxygenated derivatives (xanthophylls). More than 600 different carotenoids have been identified, which occur widely in plants, microorganisms, and animals. Carotenoids have a 40-carbon skeleton of isoprene units (Fig. 6). Their structures may be cyclised at one or both ends, have various hydrogenation levels, or possess oxygen-containing functional groups. Lycopene and $\beta$-carotene are examples of acyclic and cyclised carotenoids, respectively. Carotenoid compounds most commonly occur in nature in the all-trans form. The most characteristic feature of carotenoids is the long series of conjugated double bonds forming the central part of the molecule. This gives them their shape, chemical reactivity, and lightabsorbing properties (Adom et al. 2005).
Vitamins

The amount of vitamins in cereals is low in comparison with animal sources. Despite of this fact it is still possible to consider them the group B source of vitamins. Endosperm of cereals is low on vitamins. We can find most of the vitamins in germ and aleuronic layer. Vitamin A (retinol) is present in the form of its pro vitamin $\beta$-carotene in germ and aleuronic layer. Cereals are considered to be one of the major sources of vitamin $\mathrm{B}_{1}$, covering $40 \%$ of needs. It's present in higher concentrations in coating layer and that is why its concentration in flour depends on level of grinding. Vitamin $\mathrm{B}_{2}$ (riboflavin) is also present mainly in germ. Significant amount of vitamin $\mathrm{B}_{3}$ (nicotinic acid) is contained in wheat and barley and is concentrated in aleuronic layer, thanks to which it goes to bran. Vitamin C (L-ascorbic acid) is not present in mature 

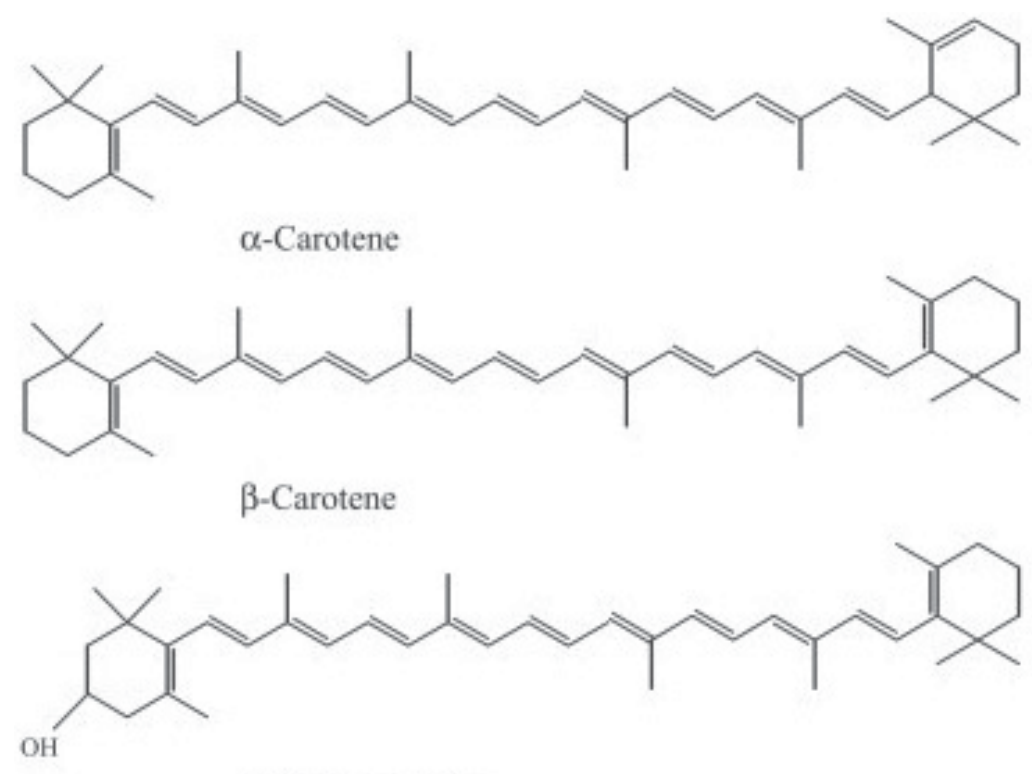

$\beta$-Cryptoxanthin<smiles>CC1=CC(O)CC(C)(C)C1/C=C/C(C)=C/C=C/C(C)=C/C=C/C=C(C)/C=C/C=C(C)/C=C/C1=C(C)CC(O)CC1(C)C</smiles>

Lutein<smiles>CC1=C(/C=C/C(C)=C/C=C/C(C)=C/C=C/C=C(C)/C=C/C=C(C)/C=C/C2=C(C)C(C)CC(O)C2)C(C)(C)CC(O)C1</smiles>

Zeaxanthin

Fig. 6. Chemical structures of common whole grain carotenoids (Liu 2007).

grain; however, its concentration is rising in germinated cereals. Vitamin PP (niacin) nicotinamide is contained in wheat and barley and is localized in aleuronic layer (Hrabě et al. 2006, Velíšek 1999). Vitamin E compounds are found in many foods including whole grains, where they are mostly present in the germ fraction. The concentration of vitamin E compounds in whole grains are: $75 \mathrm{mg} / \mathrm{kg}$ dry weight (DW) total tocopherol in soft wheat and barley; $33-43 \mathrm{mg} / \mathrm{kg}$ DW $\beta$-tocotrienol in hulled and dehulled wheat; $45 \mathrm{mg} / \mathrm{kg}$ DW $\delta$-tocopherol in corn; 56 and $40 \mathrm{mg} / \mathrm{kg}$ DW $\alpha$-tocotrienol in oats and barley, respectively (Panfili and Fratianni 2003). Vitamin $\mathrm{E}$ is the generic term used to describe a family of eight lipid-soluble antioxidants with two types of structures, the tocopherols $(\alpha$-tocopherol, $\beta$-tocopherol, $\gamma$-tocopherol, $\delta$-tocopherol) and tocotrienols $(\alpha$-tocotrienol, $\beta$-tocotrienol, $\gamma$-tocotrienol and $\delta$-tocotrienol) (Fig. 7). Their basic structures comprise a 6-hydroxychroman group and a phytyl side chain made of isoprenoid units. The chroman group may be methylated at different positions to generate different compounds with vitamin activity. Tocopherol and tocotrienol have similar structures except that tocopherols contain saturated phytol side chains while tocotrienols have three carbon-carbon double bonds in the phytol side chain. The most important functions of vitamin $\mathrm{E}$ in the body are antioxidant activity and maintenance of membrane integrity. The free hydroxyl group on the aromatic ring is responsible for the antioxidant properties and the hydrogen atom from this group can be donated to free radicals, resulting in a resonance-stabilised vitamin $\mathrm{E}$ radical. Vitamin $\mathrm{E}$ has also been shown to play a role in immune function, in DNA repair and other metabolic processes (Traber 1999).

\section{Minerals}

The mineral content of cereals ranges from 1,0 to $2,5 \%$ (Tab. 6). Elementary microanalysis of cereals has proven presence of phosphor, calcium, potassium, sodium, magnesium, iron and zinc in 

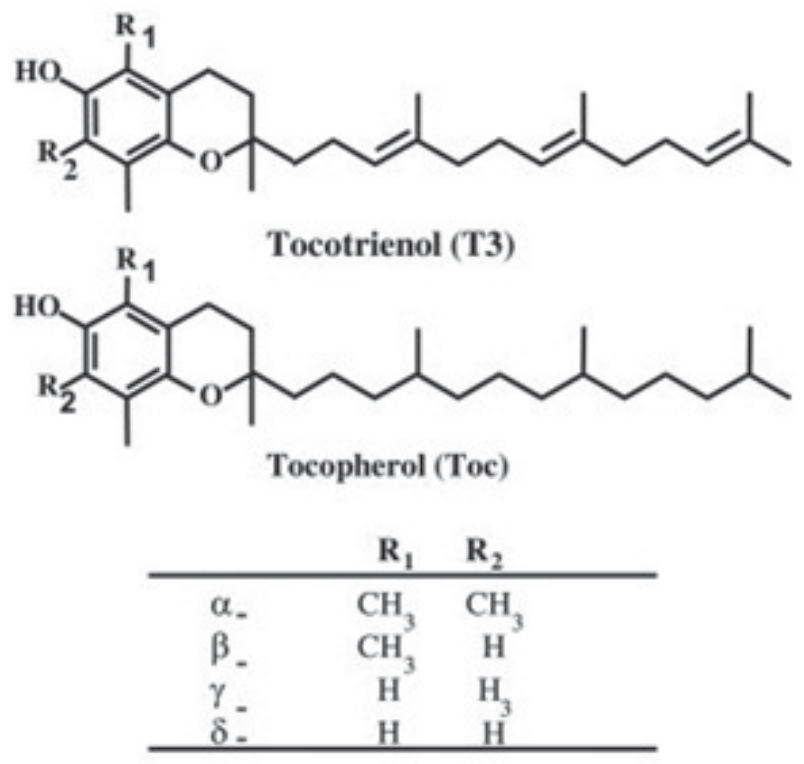

Fig. 7. Chemical structure of vitamin E. Tocotrienol (T3) has an unsaturated isooprenoid tail, and tocopherol (Toc) possesses a saturated phytyl side chain (Miyazawa et al. 2011).

Tab. 6. Mineral composition $(\mathrm{mg} / \mathrm{kg}$ ) of wheat flours and whole cereal grains (Koehler and Wieser et al. 1983).

\begin{tabular}{lcccccc}
\hline Element & Hard wheat & Soft wheat & Barley & Millet & Rye & Sorghum \\
\hline $\mathrm{P}$ & 3498 & 977,6 & 4570 & 2879 & 3620 & 349,9 \\
$\mathrm{~K}$ & 826,2 & 1225 & 4572 & 2798 & 6570 & 239,9 \\
$\mathrm{Mg}$ & 301,2 & 306,5 & 1971 & 1488 & 1328 & 187,7 \\
$\mathrm{Ca}$ & 159,5 & 202,2 & 736,2 & 508,6 & 348,7 & 27,3 \\
$\mathrm{Na}$ & 46,0 & 38,4 & 238,4 & 60,89 & 67,2 & 4,6 \\
$\mathrm{Zn}$ & 30,8 & 7,6 & 74,2 & 65,9 & 30,6 & 3,1 \\
$\mathrm{Fe}$ & 13,2 & 13,9 & 128,4 & 199,8 & 44,0 & 10,6 \\
$\mathrm{Mn}$ & 5,2 & 8,1 & 9,2 & 8,1 & 24,4 & 1,2 \\
$\mathrm{Cu}$ & 1,4 & 1,6 & 5,7 & 3,4 & 2,9 & 0,2 \\
$\mathrm{Cr}$ & 0,1 & 0,001 & 0,9 & 7,7 & 0,7 & 0,8 \\
\hline
\end{tabular}

Tab. 7. Characteristics of elements in cereals and cereal products (ASP 2004).

\begin{tabular}{|c|c|c|}
\hline & Element & Biochemical function \\
\hline \multirow[t]{5}{*}{ Basic elements } & Sodium $(\mathrm{Na})$ & $\begin{array}{l}\text { Maintaining of acid-base balance. } \\
\text { Extracellular cation, sustaining of volume of extracellular liquid in blood. }\end{array}$ \\
\hline & Potassium (K) & Intracellular cation, Maintaining of acid-base balance. \\
\hline & Calcium $(\mathrm{Ca})$ & $\begin{array}{l}\text { Healthy growth and function of bones and teeth. } \\
\text { Blood clotting. } \\
\text { Nerve and muscle excitability. }\end{array}$ \\
\hline & Phosphor (P) & Part of bones and teeth. Part of DNA, RNA, ATP, GTP and phospholipids \\
\hline & Magnesium (Mg) & $\begin{array}{l}\text { Intracellular cation, in many enzymes. } \\
\text { lowers neuromuscular excitability. }\end{array}$ \\
\hline \multirow[t]{3}{*}{ Trace elements } & Iron $(\mathrm{Fe})$ & Component of hemoglobin, myoglobin, cytochrome system \\
\hline & Zinc $(\mathrm{Zn})$ & $\begin{array}{l}\text { Cofactor of enzymes for intermediary metabolism and synthesis of proteins and } \\
\text { superoxide dismutase. } \\
\text { Control of gene transcription. }\end{array}$ \\
\hline & Copper $(\mathrm{Cu})$ & $\begin{array}{l}\text { Coenzyme of cytochrome oxidase, superoxide dismutase. } \\
\text { Healing of wounds. }\end{array}$ \\
\hline
\end{tabular}


aleuronic layer, embryo and in minimal quantity in starchy endosperm (Pedersen et al. 2007).

Elements such as $\mathrm{Zn}, \mathrm{Fe}$ and trace elements like selenium, copper and magnesium act in organism as cofactors of enzymes with antioxidant activity. Superoxide dismutase depends on $\mathrm{Zn}, \mathrm{Cu}$ and $\mathrm{Mg}$. Glutathione peroxidase and thioredoxin reductase depend on Se, and catalase on Fe. Selenium has positive effect in prevention against cardiovascular diseases and cancer and plays important role in metabolism of thyroid hormones and testosterone (important biochemical functions of minerals are summarized in Tab 7.). Concentration of these minerals in whole grains depends mainly on type of cereal and on the region of cultivation. Minerals are largely present in barn layers (in aleuronic layer), that is why whole grain products are richer on mineral elements than refined products. In flour products deprived of coating layers the loss of minerals like Fe at about $70 \%$ and $\mathrm{Zn}$ and $\mathrm{Mn}$ at about 75-80\% occurs (Libendzinska and Szefer 2006).

\section{Conclusion}

Cereals are a rich source of health-promoting substances. For the last period has been conducted many epidemiological studies have confirmed the effect of cereals in reducing the risk of lifestyle diseases. The protective effect in the development of cardiovascular disease due to lower total and LDL cholesterol and increase in HDL cholesterol was demonstrated. It also confirmed the correlation between whole grain nutrition and reducing cancer, while a diet containing whole grains may reduce the risk of cancer by $30 \%$. In studies focusing to monitor the relationship between the consumption of cereal food and body mass index values confirmed an inverse relationship, which means that with increasing consumption of whole grains, the values of body mass index are reduced and, at the same time, it facilitates the weight reduction. These and many other positive effects cereals put them in first place in our diet.

\section{Acknowledgement}

This work was supported by The Agency of the Ministry of Education, Science, Research and Sport of the Slovak Republic for the Structural Funds of EU, OP RED of ERDF in the Frame of the Project "Evaluation of natural substances and their selection for prevention and treatment of lifestyle diseases" (ITMS 26240220040).

\section{References}

AACC. (2001) Cereal Food World 46:112-113.

Abdel-Aal ESM, Huci P, Sosulski FW, Graf R, Gillott C, Pietrzak L (2001) Journal of Agriculture and Food Chemistry 49: 3559-3566.
Abdel-Aal ESM, Young JC, Rabalski I, Hucl P, FregeauReid J (2007) Journal of Agricultural and Food Chemistry 55: 787-794.

Adom KK, Liu RH (2002) Journal of Agriculture and Food Chemistry 50: 6182-6187.

Adom KK, Sorrells M, Liu RH (2005) Journal of Agriculture and Food Chemistry 53: 2297-2306.

Adom KK, Sorrells ME, Liu RH (2003) Journal of Agriculture and Food Chemistry, 51: 7825-7834.

American Dietetic Association (2008) Journal of the American Dietetic Association 108: 1716-1731.

Arnason JT, Gale J, Conilh de Beyssac B, Sen A, Miller SS, Philogene BJR, Lambert JDH, Fulcher RG, Serratos A, Mihm J (1992) Journal of Stored Products and Research, 28: 119-126.

Asp E (2010) Mineral composition. Encylopedia of Grain Science, 1st ed. vol. 2. Elsevier Academic Press p. 340-347.

Babio N, Balanza R, Basulto J, Bullo M, Salas-Salvado J (2010) Nutritional Hospital 25: 327-340.

Bekes F, Wrigley C (2004) Cereals/Protein Chemistry Encyclopedia of Grain Science. Elsevier Academic Press: Oxford, vol. 1, p. 254-262.

Belitz H-D, Grosch W, Schieberle P (2009) Cereals and cereal products.

Belitz H-D,Bender DA, Bender AE (1999) Bender's Dictionary of Nutrition and Food technology, 7th edition. Woodhead Publishing, Abington.

Beresford G, Stone BA (1983) Journal of Cereal Science, 1: $111-114$

BNF (British Nutrition Foundation) (1994) Starchy Foods in the Diet. BNF, London.

Buléon A, Colonna P, Planchot V, Ball S (1998) International Journal of Biological Macromolecules 23: 85-112.

Bunzel M, Ralph J, Martia JM, Hatfield RD, Steinhart H (2001) Journal of the Science of Food and Agriculture 81: 653-660.

Codex Alimentarius Commission (CAC) Report of the 27th Session of the Codex Committee on Nutrition and Foods for Special Dietary Uses, Bonn, Germany, 21-25 November 2005. ALINORM 06/29/26 (2006).

Colonna P, Buléon A (1992) New insights on starch structure and properties. In: Cereal chemistry and technology: a long past and a bright future. Proceedings of the 9th international cereal and bread congress, Paris pp. 25-42.

Gui W, Wood PJ, Blackwell B, Nikiforuk J (2000) Carbohydrate Polymers 41: 249-258.

Cummings JH, Mann JI, Nishida C, Vorster HH (2009) Lancet 373: 365-366.

Dammig-Adams B, Gilmore AM, Adams WW (1996) FASEB Journal 10: 403-412.

Delcour JA, Hoseney RC (2010) Principles of cereal science and technology, 3rd edn. AACCInternational, Inc, St. Paul, pp 40-85.

Dewanto XZ, Liu RH (2002) Journal of Agricultural and Food Chemistry 50: 4959-4964.

Dexter JE, Wood PJ (1996) Trends in Food Science and Technology 7: 35-41.

FAO (Food and Agriculture Organisation of the United Nations) 2011 Available at: http://faostat.fao.org/ site/368/DesktopDefault.aspx?PageID=368.

Food and Nutrition Board, Institute of Medicine (2001). Dietary reference intakes. Proposed definition of 
dietary fiber. A report of the panel on the definition of dietary fiber and the standing committee on the scientific evaluation of dietary reference intakes. Washington, DC: National Academy Press.

Goldberg G (2003) Plants: Diet and Health. The Report of the British Nutrition Foundation Task Force. Blackwell, Oxford.

Guillon F, Champ M (2000) Food Research International 3: 233-245.

Harborne JB, Williams CA (2000) Phytochemistry 55: 481-504.

Havrlentová M, Kraic J (2006) Journal of Food Research and Nutrition 45: 97-103.

Hispley EH (1953) British Medical Journal 2: 420-422.

Holtekjølen AK, Kinitz C, Knutsen SH (2006) Journal of Agricultural and Food Chemistry 54: 2253-2260.

Holtekjolen AK, Uhlen AK, Brathen ES, Sahlstrom S, Knutsen SH (2006) Food Chemistry 94: 348-358.

Hoseney RC (1994) Principles of cereal science and technology, 2nd edn. AACC, St. Paul, pp 81-101 and 229-273.

Hrabě J, Rop O, Hoza I (2006) Technologie výroby potravin rostlinného původu, UTB Zlín 178p.

Champ M, Langkilde AM, Brouns F, Kettlitz B, Collet YLB (2003) Nutrition Research Reviews 16: 71-82.

Johansson L, Virkki L, Maunu S, Lehto M, Ekholm P, Varo P (2000) Carbohydrate Polymers 42: 143-148.

Kim KH, Tsao R, Yang R, Cui SW (2006). Food Chemistry 95: 466-473.

Koehler P, Wieser H (2013) Chemistry of Cereal Grains. Handbook on Sourdough Biotechnology pp 11-45.

Kong F, Singh RP (2008) Journal of Food Science 73: 67-80.

Kritchevskya D, Shirley CC (2005) Nutrition Research 25: 413-428.

Libendzinska A, Szefer P (2006) Food Chemistry 95: $116-122$.

Liu RH (2004) Journal of Nutrition 134: 3479-3485.

Liu RH (2007) Journal of Cereal Science 46: 207-219.

Lloyd BJ, Siebenmorgen TJ, Beers KW (2000) Cereal Chemistry 77: 551-555.

Lunn J, Buttriss JL (2007) Nutrition Bulletin 32: 21-64.

Maillard MN, Berset C (1995) Journal of Agriculture and Food Chemistry 43: 1789-179.

Mann JI, Cummings JH (2009) Nutrition, Metabolism and Cardiovascular Diseases, 19: 226-229.

Mattila P, Pihlava JM, Hellström J (2005). Journal of Agricultural and Food Chemistry 53: 8290-8295.

Miyazawa T, Nakagawa K, Sookwong P (2011) Trends in Food Science \& Technology 22: 651-654.

Nilsson M, Åman P, Härkönen H, Hallmans G, BachKnudsen KE, Mazur W, Adlercreutz H (1997) Journal of Science of Food and Agriculture, 73: 143-148.

Normén L, Bryngelsson S, Johnsson M, Evheden P, Ellegard L, Brants H, Andersson H, Dutta P (2002) Journal of Food Composition and Analysis 15: 693-704.

Nugent AP (2005) British Nutrition Foundation Nutrition Bulletin 30: 27-54.

Osborne TB (1907) The proteins of the wheat kernel, vol 84. Carnegie Inst, Washington, DC.

Panfili A, Fratianni M (2003) Journal of Agriculture and Food Chemistry 51: 3940-3944.

Panfili G, Fratianni A, Irano M (2004) Journal of Agriculture and Food Chemistry 52: 6373-6377.
Parrish FW, Perlin AS, Reese ET (1960) 38: 2094-2104.

Piironen V, Lampi AM, Ekholm P, Salmenkallio-Marttila M, Liukkonen KH (2009). In Khalil K, Shewry PR (Eds.), Wheat: Chemistry and Technology, AACC International, St. Paul pp. 179-222.

Piironen V, Toivo J, Lampi AM (2002) 79: 148-154.

Poutanen K (2012) Trends in Food Science \& Technology 25: 58-62.

Ragaee S, Campbell GL, Scoles GJ, McLeod JG, Tyler RT (2001) Journal of Agriculture and Food Chemistry 49: 2437-2445.

Reimer AR, Thomson ABR, Rajotte RV, Basu TK, Ooraikul B, McBurney MI (2000) Nutrition Research 20: 851-864.

Ren Y, Ellis PR, Ross-Murphy SB, Wang Q, Wood BJ (2003) Carbohydrate Polymers 53: 401-408.

Rhodes MJ, Price KR (1997) European Journal of Cancer Prevention 6: 518-521.

Robbins RJ (2003) Journal of Agricultural and Food Chemistry 51: 2866-2887.

Ruibal-Mendieta NL, Rozenberg R, Delacroix DL, Petitjean G, Dekeyser A, Baccelli C, Marques C, Delzenne NM, Meurens M, Habib-Jiwan JL, QuetinLeclercq J (2004) Journal of Agricultural and Food Chemistry 52: 4802-4807.

Saikia D, Deka S (2011) International Food Research Journal 18: 21-30.

Sajilata MG, Singhal RS, Kulkarni PR (2006) Food Science and Food Safety 5: 1-17.

Saura-Calixto F (2011) Journal of Agriculture and Food Chemistry 59: 43-49.

Sharma A, Yadav BS (2008) Food Reviews International 24: 193-234.

Shibanuma K, Takeda Y, Hizukuri S, Shibata S (1994) Carbohydrate Polymers 25: 111-116.

Skendi A, Biliaderis CG, Lazaridou A, Izydorczyk MS (2003) Journal of Cereal Science, 38: 15-31.

Slavin J (2003) Proceedings of the Nutrition Society 62: 129-134.

Smith MM, Hartley RD (1983) Carbohydrate Research 118: 65-80.

Sosulski F, Krygier K, Hogge L (1982) Journal of Agriculture and Food Chemistry 30: 337-340.

Spiller GA (1993) Definition of dietary fiber. In Spiller, G.A. (Ed.) CRC Handbook of Dietary Fiberin Human Nutrition. CRC Press Boca Raton p. 15.

Subba MV, Muralikrishna G (2002) Journal of Agricultural and Food Chemistry 50: 889-892.

Theuwissen E, Mensink RP (2008) Physiology \& Behavior 94: 285-292.

Trumbo P, Schlicker S, Yates AA, Poos M (2002) Journal of the American Dietetic Association 11: 1621-1630.

Velîšek, J (1999) Chemie potravin 2, Tábor: OSSIS 328 p (in Czech).

Vitaglione P, Napolitano A, Foliano V (2008) Trends in Food Science \& Technology 19: 451-461.

Wieser H, Seilmeier W, Eggert M, Belitz H-D (1983) Z Lebensm Unters Forsch 177: 457-460.

Wood PJ (1994) Carbohydrate Polymers 25: 331-336.

Wood PJ, Weisz J, Fedec P, Burrows VB (1989) Cereal Chemistry, 66: 97-101.

Yang F, Basu TK, Ooraikul B (2001) International Journal of Food Science and Nutrition 52: 319-33.

Zobel HF (1988) Starch/Stärke 40: 1-7. 